\title{
Chapter 3 \\ Territory in the Law of Jurisdiction: Imagining Alternatives
}

\author{
Cedric Ryngaert
}

\begin{abstract}
Territory is central to the doctrine of international jurisdiction. However, the use of territory as the jurisdictional linchpin is a political choice, the result of a confluence of historically specific political, material, epistemic, and above all mapping practices. The political contingency of territory begs the question whether alternative, non-territorial jurisdictional concepts could be contemplated. In this contribution, community, temporality, and justice are explored. The territorial imbrications of these jurisdictional alternatives are acknowledged, but it is highlighted how territory can in fact be re-conceptualized in the service of 'its others'. Opting for the 'others' and for a novel conceptualization of territory remains a political choice. However, the political character of jurisdiction is not something to lament, but rather to celebrate, as it creates opportunities for a variety of political actors to have an impact on the actual application and construction of the un(der)determined notions of jurisdiction and territory, and ultimately on the modes of exercise of public authority. The salience of these theoretical ideas is exemplified by applying them to the case of transnational human rights litigation against corporations, a manifestation of socio-legal globalization that encapsulates the key role played by jurisdiction in negotiating claims of authority.
\end{abstract}

Keywords Territory - Jurisdiction - Space - Community • Time • Justice • Legal theory $\cdot$ Human rights $\cdot$ Litigation

Professor of Public International Law, Utrecht University. The research which resulted in this publication has been funded by the European Research Council under the Starting Grant Scheme (Proposal 336230-UNIJURIS) and the Dutch Organization for Scientific Research (NWO) under the VIDI Scheme (No. 016.135.322).

C. Ryngaert $(\square)$

Utrecht University, Utrecht, The Netherlands

e-mail: C.M.J.Ryngaert@uu.nl 


\section{Contents}

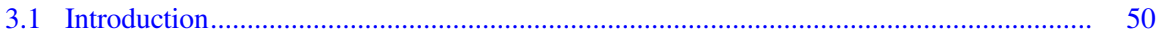

3.2 The Centrality of Territory in the Modern Legal Doctrine of Jurisdiction .................... 53

3.3 Unpacking the Epistemic Bias Toward Territory ............................................................. 56

3.4 Non-Spatial Alternatives to Territory ………..................................................... 59

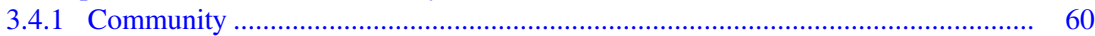

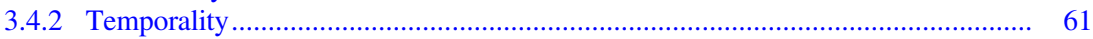

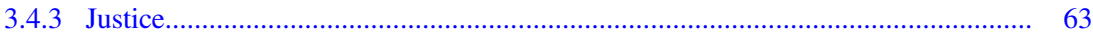

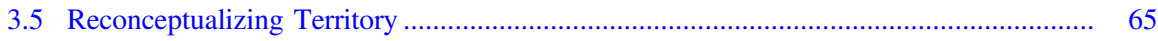

3.6 Acknowledging the Political Nature of the 'New Territoriality' ................................... 68

3.7 Beholding Transnational Human Rights Claims: Donning Spatial and Non-Territorial

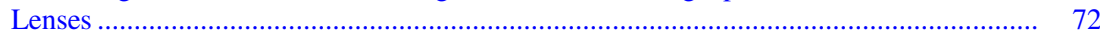

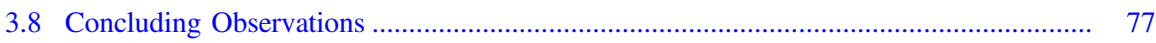

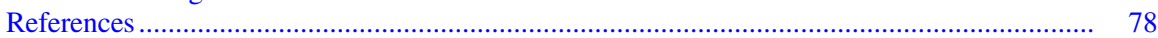

\subsection{Introduction}

In 2014, an author writing in the European Journal of International Law characterized this author as 'one of the border guards of borders'. ${ }^{1}$ I take it that he did not necessarily mean this disparagingly. Implicitly, however, he may have accused me of believing that territoriality continued to call the shots in the law of jurisdiction, while neglecting its shifting foundations in theory and practice. I am not a person to staunchly defend earlier work or to crusade against perceived slights. Rather, I have taken this characterization - which in fact, given the centrality of territoriality in my earlier (largely doctrinal) work, I am ready to acknowledge as largely accurate - as an invitation to indeed problematize territoriality and to take seriously the ominous warnings of 'the end of geography'. ${ }^{2}$ After all, as Shakespeare wrote in King Lear, ' $[\mathrm{t}]$ here is nothing so confining as the prison of our perceptions.' 3

To problematize and perhaps eventually change perceptions, we should first try to understand them at a deeper level and to explore how we have acquired and continue to hold them in the first place. This is not very different from how a doctor tries to understand and remedy an ailment. Using a range of diagnostic techniques, she aims to determine what disease explains a patient's symptoms; on the basis of

\footnotetext{
${ }^{1}$ Landauer 2014, at 32.

${ }^{2}$ Landauer was in fact responding to a published lecture delivered by Daniel Bethlehem, titled 'The End of Geography: The Changing Nature of the International System and the Challenge to International Law', in which Bethlehem, while observing that state jurisdiction 'is largely manifested in territorial terms' (Bethlehem 2014, at 14), called for a more flexible conception of jurisdiction termed 'deemed jurisdiction', which, especially in cyberspace, would 'move the competence that is asserted closer to the technical and away from the political'. Note that the notion of 'the end of geography', as a consequence of globalization, has been around in political science circles for some time. See, notably, Greig 2002.

${ }^{3}$ Shakespeare 1623. See also John H Patterson: 'Only fools and dead men do not change their minds. Fools will not and dead men cannot'.
} 
the diagnostic opinion reached, the doctor proposes treatment. ${ }^{4}$ As I am supposed to be a learned doctor myself, there is even more merit in auto-applying this medical approach to a patient suffering from the affliction of territorial bias. ${ }^{5}$

The obstinacy of territoriality in the law of jurisdiction is obviously related to the spell that the political concept of state sovereignty, and its legal overtones of regulatory exclusivity, has cast over our legal imagination. Jurisdiction has come to be seen as the practical, legal instantiation of political power and authority over a given territory, with territorial jurisdiction giving spatial form and meaning to legal relations. ${ }^{6}$ Jurisdiction is the 'quotidian' and instrumental reflection of the political-theological concept of sovereignty, ${ }^{7}$ which, inextricably tied up as it is with 'the state', suffers from its own territorial bias.

Precisely because lawyers consider territory as pre-given political knowledge, they have difficulties in imagining jurisdiction in non-territorial terms. They may even refrain from trying in the first place, believing it to be beyond their epistemic domain. Imagination may not be the preserve of lawyers indeed. As Douzinas and Nead wrote in 1999, '[1]awyers live by the text and love the past, they hate novelty and misunderstand new languages. ${ }^{8}$ They do not like 'imagining', as (artistic) imagery 'breaks away from conventions and rules and expresses creative freedom and imagination' and thus forms the antithesis of law. Imagination is, however, precisely what is needed to breathe new life into the stale, territory-based concept of jurisdiction.

Lawyers would do well to take some inspiration from political scientists in this respect, who have demonstrated daring in reconceiving of jurisdiction's sister concept sovereignty. Jens Bartelson, for instance, has argued that, thanks to the linguistic turn in philosophy and the social sciences, 'sovereignty is what we make of it through our linguistic practices, given the contextual constraints at hand', ${ }^{10}$ and thus that sovereignty should not be considered as necessarily territorially bounded. Accordingly, sovereignty may have no meaning apart from its actual function, which might be being an instrument of global governance. ${ }^{11}$ When we agree that jurisdictional representations should track evolutions in the political representation of sovereignty, and that lawyers are the class of technicians giving concrete societal shape to political change, also lawyers cannot escape imagination. In this process of imagination, legal experts dealing more specifically with issues of

\footnotetext{
${ }^{4}$ See more at length Treasure 2011.

${ }^{5}$ There is in fact a lively literature on what we can learn from doctors, especially in business studies. See, e.g., Nohria 2012.

${ }^{6} \mathrm{Cf}$. Dorsett and McVeigh 2012, at 40 (submitting that 'sovereign territorial jurisdictions provide the means of organizing relations between laws').

${ }^{7}$ Kaushal 2015, at 781 (arguing that 'jurisdiction locates questions about state power in quotidian legal practice while sovereignty locates them in political theology').

${ }^{8}$ Douzinas and Nead 1999, at 1.

${ }^{9}$ Ibid.

${ }^{10}$ Bartelson 2014, at 10.

${ }^{11}$ Ibid., at 69.
} 
jurisdiction should realize the crucial role they play as 'constitutors' of the law. After all, jurisdiction is 'the political heart of the juridical order'; ${ }^{12}$ it inaugurates law and governance by producing the latter's authority. Unless an actor has jurisdiction in the first place, it cannot produce law. ${ }^{13}$

In this contribution, imagination is precisely what is endeavored. I prepare the field by outlining the centrality of territory in the dominant doctrine of international jurisdiction, espoused by leading writers and practitioners (Sect. 3.2). I go on to unpack the epistemic bias towards territory in the international legal profession, exploring what underlies our preference for a physical boundary-based jurisdictional system (Sect. 3.3). Having laid bare the implicit political choice to propel territory to such prominence, I try to imagine some alternative, non-territorial jurisdictional beginnings, based on community (a principle with its own history), temporality, and justice (Sect. 3.4). I acknowledge the territorial imbrications of these alternatives, but I highlight how territory can in fact be re-conceptualized in the service of 'its others', set out in Sect. 3.5. It is true that opting for the 'others' and for a novel conceptualization of territory remains a political choice. However, the political character of jurisdiction is not something to lament, but rather to celebrate. Acknowledging it makes transparent that jurisdiction and territory are sites in which various political imaginations of global jurisdictional order, including non-territorial ones, are, and can be advanced and mediated (Sect. 3.6). This creates opportunities for a variety of political actors to have an impact on the actual application and construction of the un(der)determined notions of jurisdiction and territory, and ultimately on the modes of exercise of public authority. The salience of these theoretical ideas is exemplified by applying them to the case of transnational human rights litigation against corporations, a manifestation of socio-legal globalization that encapsulates the key role played by jurisdiction in negotiating claims of authority (Sect. 3.7). Section 3.8 concludes.

In this contribution 'territory' and 'territoriality' are used as slightly distinct concepts. However, the reductionist temptation is avoided to conceive of 'territory' as just physically bordered land or to conceive of 'territoriality' as just denoting a relationship with, or quality of territory (the Latin suffix '-alis'). Rather, relying on geographer Stuart Elden, territory is approached in more conceptual terms, as a historical, geographical, and political question. ${ }^{14}$ Relying on another geographer, Robert Sack, territoriality is defined as 'the attempt to affect, influence, or control actions, interactions $[\ldots]$ by asserting and attempting to enforce control over a geographic area' ${ }^{15}$

\footnotetext{
${ }^{12}$ Kaushal 2015, at 788 .

${ }^{13}$ Valverde 2009, at 141 and 144 (writing that 'the governance of legal governance is the work of jurisdiction', and that 'jurisdiction sorts the where, the who, the what, and the how of governance').

${ }^{14}$ Elden 2013, at 328 .

${ }^{15}$ Sack 1983, at 55.
} 
The theoretical argument made in this contribution is that the concepts of jurisdiction, spatiality, and territoriality are socially and politically constructed. Methodologically speaking, constructivism, critical legal studies, and critical geography are resorted to. Taking the cue from the constructivist tradition in international relations, the contribution posits that our ideas, norms and beliefs affect how we conceive of material space, territory, and 'the state'. ${ }^{16}$ From a critical legal studies perspective, such ideas, norms and beliefs are assumed to be politically contingent, volatile, and subject to constant contestation, with every equilibrium reached being open to challenge by a variety of actors propounding different interpretations. Like critical geographers, the nature of territory as political technology is acknowledged, and alternative spatial and non-spatial representations of authority are explored.

\subsection{The Centrality of Territory in the Modern Legal Doctrine of Jurisdiction}

It is stating the obvious that the practice and theory of modern international law is centered around state sovereignty and territory. ${ }^{17}$ Without much hesitation, contemporary writers and practitioners on international law and jurisdiction consider the principle of territoriality to be the bedrock of the law of jurisdiction. ${ }^{18}$

The primacy of territoriality is arguably derived from the principles of sovereign equality and non-intervention. ${ }^{19}$ These principles, most clearly enunciated in the 1928 Island of Palmas arbitral award, ${ }^{20}$ go to the very heart of the international legal system, and consider territorially delimited states as equal subjects of international law whose territorial sovereignty is not to be encroached upon by their peers. ${ }^{21}$ Thus, as FA Mann held, '[s]tate legislation as would have the effect of regulating the conduct of foreigners in foreign countries', would be unlawful. ${ }^{22}$ In essence, the law of jurisdiction ensures that state competences are properly allocated, with the most

\footnotetext{
${ }^{16}$ E.g., Wendt 1999.

${ }^{17}$ Dorsett and McVeigh 2012, at 40: 'The traditional formulations of international law are both conceptually and institutionally organized around the forms of the sovereign territorial state.'

${ }^{18}$ E.g., Hirst 2003, at 45; Ryngaert 2015a, at 49. In its Report on Extraterritorial Jurisdiction (2009), the International Bar Association rather unambiguously stated that ' $[t]$ he starting point for jurisdiction is that all States have competence over events occurring and persons ... present in their territory.' International Bar Association 2009. On occasion, writers may reserve some room for the nationality principle as well. Oxman 2007, para 11.

${ }^{19}$ Compare Mann 1984, at 20 (arguing that there exists merely a terminological difference between sovereignty, territoriality, and the principle of non-intervention).

${ }^{20}$ Island of Palmas Case (Netherlands v United States of America), Permanent Court of Arbitration, Arbitral Award, Case No. 1925-01, 4 April 1928, at 838 ('Sovereignty in the relations between States signifies independence. Independence in regard to a portion of the globe is the right to exercise therein, to the exclusion of any other State, the functions of a State').

${ }^{21}$ Ryngaert 2015a, at 36; Buxbaum 2009, at 668.

${ }^{22}$ Mann 1964, at 47.
} 
natural allocative principle being the physical, clear boundary-based principle of territoriality. Ordinarily, in order to preserve the status quo of competence allocation, states will tend to protest other states' assertions of extraterritorial jurisdiction, thereby further cementing the exclusivity of territoriality. ${ }^{23}$

Key is that, at a meta-level, the doctrine does not question the legitimacy of the principle of territoriality. Controversy merely focuses on the exact scope of application of the principle, in its objective and subjective iterations. Indeed, the dominant theory of ubiquity, pursuant to which territorial jurisdiction obtains as soon as one of the constituent elements of the wrongful activity are located on a state's territory, the legal inquiry turns on the intensity of territorial effects and territorial acts required to trigger application of the territoriality principle. ${ }^{24}$ Thus, for instance, in Morrison (2010), the US Supreme Court ruled that the focus of a statute has to be determined for purposes of determining whether a particular application of the statute is or is not extraterritorial. ${ }^{25}$ The Court did not doubt the validity of the congressional presumption against extraterritoriality, however, nor do courts and legislators more generally question territory as the ordering principle (in spite of the at times artificial reliance on territory).

It is observed that at a more doctrinal level, the spatial knowledge regarding territoriality in the law of jurisdiction was consecrated rather late. It is recalled that in the 1927 Lotus (France v Turkey) judgment, the Permanent Court of International Justice (PCIJ) famously held that '[f]ar from laying down a general prohibition to the effect that States may not extend the application of their laws and the jurisdiction of their courts to persons, property and acts outside their territory, it leaves them in this respect a wide measure of discretion, which is only limited in certain cases by prohibitive rules; as regards other cases, every State remains free to adopt the principles which it regards as best and most suitable. ${ }^{26}$ On its face, Lotus considered the exercise of extraterritorial jurisdiction to be presumptively lawful, at least absent a prohibitive customary or treaty rule to the contrary, and thus to cast doubt on the pre-eminence of territoriality. ${ }^{27}$ The PCIJ's stance in Lotus represents the high-water mark of jurisdictional liberalism. Importantly, it has not explicitly

\footnotetext{
${ }^{23}$ The law of jurisdiction evolves on the basis of action and reactions, with the latter-or the absence thereof-determining the legality of the former. See Akehurst 1975, at 176. Protest is typically couched in the language of extraterritoriality. E.g., comment c to para 442(1)(c) of the Restatement (Third) of US Foreign Relations Law (1987), discussing European states' reactions to US discovery orders for the production of documents located within European states' territory (American Law Institute 1987).

${ }^{24}$ Vagias 2014, at 6-7; Lowe and Staker 2010, at 322; Ryngaert 2009.

${ }^{25}$ Morrison et al. $v$ National Australia Bank Ltd. et al., Supreme Court of the United States, Opinion, 561 U.S. 247, 24 June 2010, at 266-269.

${ }^{26}$ Case of the SS Lotus (France v Turkey), PCIJ, Judgment, 27 September 1927 ('Lotus'), para 46.

${ }^{27}$ A close reading of the judgment reveals, however, that this may not be what the Court actually intended. Indeed, it also held that 'in all systems of law the principle of the territorial character of criminal law is fundamental', and that 'the exclusively territorial character of law relating to this domain constitutes a principle which, except as otherwise provided, would ipso facto, prevent States from extending the criminal jurisdiction of their courts beyond their frontiers'). Lotus, at 20.
} 
been repudiated by the PCIJ's successor, the International Court of Justice (ICJ). Nevertheless, in the 1970 Barcelona Traction case, the ICJ recognized that the principles of states sovereignty and non-intervention required the imposition of limits on the exercise of jurisdiction. ${ }^{28}$

By 1970, in any event, the Lotus-based jurisdictional free-for-all had been largely abandoned in the doctrine, and territoriality had risen to prominence as the chief principle of jurisdiction. Notably the influential 1935 Harvard Research Draft Convention on Jurisdiction with respect to Crime has been instrumental in this respect. $^{29}$ The Harvard Draft Convention, which was admittedly never formally adopted by states but can partly be read as an indictment of the Lotus liberalism, backed territoriality as the basic principle of jurisdiction. In so doing, it harked back to Vattel, who as the first modern international law writer emphasized the centrality of territory in the law of jurisdiction, ${ }^{30}$ and even to Baldus, who as early as the late Middle Ages poetically posited that territory and jurisdiction 'go together as mist to a swamp'. 31 The Draft Convention, exceptionally, and in limited circumstances, also allowed the exercise of jurisdiction on some other grounds (personality, security, universality) on the basis of prevailing (and still current) state practice. Most of these exceptions, while formally 'extraterritorial', have their roots in territoriality after all, however. ${ }^{32}$ The personality principle operates on the basis of the perpetrator or victim's nationality of a territorially delimited state, and the security or protective principles operates on the basis of threats to the political sovereignty and independence of, again, such a state. Universality does not (necessarily) refer back to territorial state interests, but its practical importance is negligible, as only a limited number of offenses are amenable to universal jurisdiction, and only a handful of cases arising under the universality principle have made it to the trial case. ${ }^{33}$ Yet even the exercise of universal jurisdiction has a

\footnotetext{
${ }^{28}$ Barcelona Traction, Light and Power Company, Limited (Belgium v Spain), ICJ, Judgment, 5 February 1970, para 105. Compare Case concerning the Arrest Warrant (Democratic Republic of the Congo v Belgium), ICJ, Merits, Judgment, 14 February 2002, Separate Opinion of President Guillaume, para 15 ('The adoption of the United Nations Charter proclaiming the sovereign equality of States, and the appearance on the international scene of new States, born of decolonization, have strengthened the territorial principle').

${ }^{29}$ American Society of International Law (1935) Draft Convention on Jurisdiction with Respect to Crime, American Journal of International Law 29:439-442 ('Harvard Draft Convention')

${ }^{30}$ de Vattel 1710, para 84 (emphasis added) ('The sovereignty united to the domain establishes the jurisdiction of the nation in her territories, or the country that belongs to her. It is her province, or that of her sovereign, to exercise justice in all the places under her jurisdiction, to take cognisance of the crimes committed, and the differences that arise in the country').

${ }^{31}$ Elden 2013, at 36, fn 149, also writing that 'jurisdiction inheres in a territorio [...] but a territorium has its own boundaries' (fn 148). Note that in Baldus' time - characterized by city-states - the concept of state sovereignty was not fully developed yet, so that Baldus may possibly not be considered as the 'father' of the contemporary paradigm of exclusive jurisdictional sovereignty of the state.

${ }^{32}$ Maier 1996, at 65

${ }^{33}$ See Langer 2011.
} 
territorial dimension, in that the territorial presence of the presumed offender is normally required as a trigger. ${ }^{34}$

The territorial bias of the Harvard Draft Convention has cast a long shadow in the practice of states. ${ }^{35}$ At the same time, it has become a lightning rod for critics of the jurisdictional-territorial-status quo. ${ }^{36}$ In this contribution, I join this chorus of critics. Importantly, I develop a theoretical rather than doctrinal argument. In the next section, I start with unpacking the international legal profession's epistemic bias in favor of territoriality.

\subsection{Unpacking the Epistemic Bias Toward Territory}

The doctrinal pre-eminence of territory in the law of jurisdiction elicits the obvious question as to how come territory ultimately carried the day as the jurisdictional linchpin, sidelining and eliminating alternative jurisdictional concepts, particularly those based on personality and community. ${ }^{37}$ A variety of explanations have been proffered in this regard, ranging from the rediscovery of Roman law in the twelfth century, economic evolutions, centralizing tendencies in burgeoning governmental administrations, and epistemic changes. ${ }^{38}$ These explanations are valid in their own right, but what has really propelled territory as the principle of jurisdictional order, is arguably the rise of cartography and grid-based, Ptolemaic maps, developed from the sixteenth century onwards. Geometrical maps gave each place on the map equal prominence and clearly demarcated boundaries between territories. These new cartographic practices gradually led to changing ideas about appropriate and legitimate governance, finally ushering in novel political practices that presented

\footnotetext{
${ }^{34}$ E.g., Article 2(1)(a) of the Dutch International Crimes Act. Territory also informs the operation of the principle of aut dedere aut judicare, which often constitutes the treaty basis for 'universal jurisdiction'. E.g., Article 5(2) ('Each State Party shall likewise take such measures as may be necessary to establish its jurisdiction over such offences in cases where the alleged offender is present in any territory under its jurisdiction and it does not extradite him pursuant to article 8 to any of the States mentioned in paragraph I of this article [these are the States who can exercise jurisdiction on the basis of another permissive principle].' The operation of this principleextradite or prosecute-logically requires territorial presence, as the custodial state cannot extradite a person whom it has not first arrested on its territory.

${ }^{35}$ See Ryngaert 2015a, at 77-99, for an overview of the variety of assertions made by states under the territoriality principle.

${ }^{36}$ This argument is made more in particular by authors dealing with transnational computer crime and data protection violations, which take place in a largely virtual, de-territorialized sphere. Svantesson 2015.

${ }^{37}$ Grotius, for instance, defined jurisdiction as the authority exercised over 'two subjects, primarily persons', and only secondarily refer to 'the place, which is called territory' as the relevant jurisdictional nexus. Elden 2013, at 238, fn 230.

${ }^{38}$ Ruggie 1993.
} 
territorially bounded political space and the attendant exclusive territorial jurisdiction of the State as logical and natural phenomena. ${ }^{39}$ These practices are variously grounded on the need for global order (international lawyers), on the domestic social contract (constitutional theorists), or simply on the visual features of the natural environment (all), even if these justifications have considerable shortcomings.

A territory-based jurisdictional order is inherently attractive to the international lawyer, since it does away with overlapping jurisdictional allegiance. Thereby, it arguably creates international order, stability, predictability, peace and security. These are the traditional goals of international law itself. ${ }^{40}$ Admittedly, this idea of territoriality as order and predictability has inched closer to an ideal type as, in reality, acts and events cannot be located in just one place, in our current interconnected world; instead, they have worldwide effects. In an age of increasing digitalization, and de-territorialized cloud computing, territory, or its 'territorial effects' iteration, may even have become nonsensical. ${ }^{41}$ Nevertheless, it remains that, even in respect of borderless phenomena, regulators continue to rely on territoriality with its connotation of regulatory exclusivity, and have no qualms feigning the principle's ordering potential. ${ }^{42}$

\footnotetext{
${ }^{39}$ Branch 2011, 2013.

${ }^{40}$ Abass 2014, at 18-20. This classic idea of allocating acts and events to just one sovereign can notably be found in the 1908 US Supreme Court judgment in the American Banana antitrust case, where the Court held that ' $[\mathrm{t}$ ] he general and almost universal rule is that the character of an act as lawful or unlawful must be determined wholly by the law of the country where the act is done', citing in this respect the principles of justice and non-interference. American Banana Co. v United Fruit Co., 213 US 347, 26 April 1909, at 356.

${ }^{41}$ Svantesson 2015 , at $69-70$, suggesting as jurisdictional principles, instead of territoriality, connections, interests, and reasonableness (at 74), but reasoning mainly from a cyberspace perspective. See also Schultz 2008, at 815 (rejecting the application of the territorial effects doctrine to cyberspace).

${ }^{42}$ Ryngaert 2015b; E.g., in accordance with its Aviation Directive (Directive 2008/101/EC of the European Parliament and of the Council of 19 November 2008 amending Directive 2003/87/EC so as to include aviation activities in the scheme for greenhouse gas emission allowance trading within the Community, [2009] OJ L 8/3 ('Aviation Directive')), the EU considers a foreign aircraft's departing from, or landing at an aerodrome located within its territory, as a sufficient territorial nexus for the application of EU law to the entire flight trajectory, including outside EU airspace. The Court of Justice of the European Union has found the approach to be in keeping with the territoriality principle under customary international law, see Case C-366/10: (Air Transport Association of America and Others $v$ Secretary of State for Energy and Climate Change), ECJ Grand Chamber, Judgment, ECR I-13755, 21 December 2011 ('Air Transport Association of America and Others'). Also, in accordance with the 1982 United Nations Convention on the Law of the Sea, 1833 UNTS 3, it is the port state, meaning the state whose ports are visited by a vessel, who may exercise specific legislative and enforcement powers over the vessel, in accordance with Articles 211(3), 218, and 219 of the Convention. Furthermore, Article 4(1)(a) of Directive 95/46/EC of the European Parliament and of the Council of 24 October 1995 on the protection of individuals with regard to the processing of personal data and on the free movement of such data [1995] OJ L 281/31 provides that 'Each Member State shall apply the national provisions it adopts pursuant to this directive to the processing of personal data where: (a) the processing is carried out in the context of the activities of an establishment of the controller on the territory of the Member State $[\ldots]$ ' (emphasis added).
} 
Territory has not only cast a jurisdictional spell on international lawyers but also on constitutional lawyers and theorists. Seemingly, territory offers a rationale for the very authority of the law, insofar as the social contract is seen as revolving around territory. By their very act of entering or residing in the sovereign's territory, individuals can be presumed to consent to the law, thereby legitimating governmental coercion. This territorial aspect of the social contract theory was most clearly enunciated by John Locke in his Second Treatise of Government (1689), where he wrote as follows: 'If a man owns or enjoys some part of the land under a given government, while that enjoyment lasts he gives his tacit consent to the laws of that government and is obliged to obey them [...]. It holds indeed if he is only travelling freely on the highway; and in effect it holds as long as he is merely in the territories of the government in question. ${ }^{43}$ Accordingly, Locke considered voluntary territorial presence as tacit consent to governmental coercion, thereby transforming such coercion into legitimate authority and jurisdiction. This rationale later came to underlie the due process-based doctrine of personal jurisdiction in the United States, pursuant to which minimum (territorial) contacts with the US suffice for a person to be put on notice of being subject to US jurisdiction. ${ }^{44}$ It has also legitimated the application of a host of import/export requirements imposed on goods crossing the border. ${ }^{45}$ In the eighteenth century, the principle of democracy was grafted onto the already constructed nexus between sovereignty and territory, thereby reinforcing the latter's inevitability as the nec plus ultra of legitimate governance. Democracy and popular sovereignty were considered as realizable only in polities with recognizable physical boundaries, ${ }^{46}$ and the nation-state based community became the primary, and even quasi-exclusive, political community. However, why the social contract should be cast in territorial terms remains unexplained by these theories. After all, decisions on drawing the territorial boundaries themselves, or on the use of the concept of territoriality as the very mode of governance, have not been taken on the basis of consent. ${ }^{47}$ Accordingly, these theories suffer from a petitio principii as they simply posit or accept the inevitability of territory as a mode of governance. ${ }^{48}$

\footnotetext{
${ }^{43}$ Locke 2012, para 119.

${ }^{44}$ Brilmayer 1987; World-Wide Volkswagen Corp. $v$ Woodson, Supreme Court of the United States, Opinion, 444 US 286, 21 January 1980; International Shoe v State of Washington, Supreme Court of the United States, Opinion, 326 US 310, 3 December 1945; Goodyear Dunlop Tires Operations, S.A., et al. v Brown et UX., co-administrators of the Estate of Brown et al., Supreme Court of the United States, Opinion, 564 U.S. 915, 27 June 2011; Daimler AG v Bauman, Supreme Court of the United States, Opinion, 134 S. Ct. 746, 14 January 2014.

${ }^{45}$ Howse and Regan 2000, at 374.

${ }^{46}$ Radon 2004, at 199.

${ }^{47}$ Bartelson 2014, at 30 (questioning whether boundaries and the restrictions they pose are democratic and noting that "everyone is subjected to some sovereignty authority simply by virtue of inhabiting some portion of planetary space, irrespective of whether they have consented to subjection or not').

${ }^{48}$ Brilmayer 1987, at 309 (submitting that 'the tacit consent argument turns on prior notions that a state has a right to regulate within its own boundaries').
} 
In spite of the apparent practical and theoretical shortcomings of the concept of territoriality, the intellectual prison which territory has created, remains also intuitively hard to escape. This is so for two reasons. First, territory's visual representation on a map, containing unambiguous boundaries, makes territorial jurisdiction straightforward and easy to comprehend (see also the next section). Second, territory has an undeniable natural and physical character. In this respect, the reduction of the juridical conception of the 'bordered territory' to 'a brute, physical landscape' 'effaces but reinforces the normative assumption that territory is the fixed and eternal site of politics'. 49 The naturalization or 'physicalization' of territory may thus render the 'territorial trap', ${ }^{50}$ which refers to the epistemic bias of international relations theory, seemingly unavoidable.

\subsection{Non-Spatial Alternatives to Territory}

In spite of the extant, hard-to-escape, epistemic basis in favor of territory, critical scholars - especially outside, or on the fringes of legal scholarship - have not given up on imagining alternatives to jurisdictional territoriality. Shah, for instance, called on scholars to study conceptions of spatiality other than territory and notably to explore 'the global' as political theory. In her view, 'global' as a constitutive spatial-political category could reshape how we normatively conceive of legitimate authority. ${ }^{51}$ This would allow us to imagine jurisdiction beyond the confines of the territorial State, and give us the analytical tools to jurisdictionally address de-territorialized, global or transnational problems that cannot easily be tied down to the territory of just one or only a handful of states.

One should admit that for geographically-minded scholars-which most of us are-properly representing the non- or extra-territorial in space is an uphill struggle, as non-territorial or even non-state political authority is not easily (cartographically) mapped and represented. Nevertheless, digital technology may possibly enable us to depict nonlinear jurisdictional spaces, e.g., transnational functionally differentiated epistemic or other communities living by their own norms, such as game-centered communities governed by bylaws. After all, even without such technology, our late-medieval forebears were somehow able to map complex jurisdictional loyalties through itinerary maps, mappaemundi, and item-based lists. ${ }^{52}$ Non-state authority may not easily map onto a geometric grid-based map, but such authority still inhabits a space and has certain boundaries. As Hans Lindahl observed, '[t]he law governs human behavior, and human behavior takes place in space', and spatial boundedness also holds for transnational private authority and

\footnotetext{
${ }^{49}$ Shah 2012, at 67.

50 Agnew 1994.

${ }^{51}$ Shah 2012, at 71.

${ }^{52}$ Branch 2011, at 9-10 and 30.
} 
regulation. ${ }^{53}$ If one is indeed willing to accept that a regulatory community necessarily has boundaries, even if non-geographical ones, depiction of these boundaries may not be impossible.

Alternatively, one could simply forego spatiality as a useful category to capture the jurisdictional complexities of our current era-and thus abandon political geography as a discipline that can relevantly analyze non-cartographic political and legal realities. This should not equal epistemic defeat but rather invite us to consider other analytical and disciplinary lenses to behold a changed world. Note in this respect that complex allegiances in the Middle Ages were not mapped either, at least not in the strict sense of the word; item-based lists simply described jurisdictional rights, obligations, and places, and did not depict extended geographic spaces over which jurisdiction would be exercised. ${ }^{54}$ In this section, I explore and imagine 'community', 'temporality', and 'justice' as promising alternative, non-spatial concepts of jurisdiction.

\subsubsection{Community}

If we take medieval allegiances as our jurisdictional point of departure, recalling that contemporary history is never made ex nihilo, it may be worthwhile to study membership in a community as a historically tried counterpoint to territoriality. Until the Modern Age, governance and law were indeed based on personal, sometimes tribal allegiances rather than territorial location. ${ }^{55}$ Some decades ago, sociologists have already predicted a return to this 'tribalism', as people grow disenchanted with a dehumanizing modernity, and look for identity within communities rather than territory-based institutions. ${ }^{56}$ In contemporary scholarship, Paul Schiff Berman, drawing also on ethnographic research with respect to identity-formation, has picked up this disenchantment, and suggested community as the relevant jurisdictional linchpin. Arguably, a changing social context characterized by multiple identifications has yielded unified but overlapping communities that can be non-territorial and decoupled from physical location; hence, jurisdiction should become a function of which community, including transnational community,

\footnotetext{
${ }^{53}$ Lindahl 2010, at 34 and 39. See also ibid., at 36 ('A legal space is never only a geographical surface [...] but rather a concrete articulation of normative and physical dimensions').

${ }^{54}$ E.g., the division of Charlemagne's empire into three parts in the early medieval Treaty of Verdun $(843 \mathrm{AD})$ 'was framed in terms of jurisdictions and revenues, not territory per se'. Branch 2013 , at 25 .

${ }^{55}$ Kassan 1935 , at 240 . We can find the roots of the personality principle in these allegiances. One could thus safely state that the personality principle is older than the territoriality principle. See also Lowe and Staker 2010, at 323. Note that Morgan, one of the fathers of modern anthropology, traces only two sorts of human governance: governance based on territory, and governance based on community (Morgan 1877).

56 E.g., Maffesoli 1995.
} 
rather than territorially delimited state, has ties with a dispute. ${ }^{57}$ This theory is both descriptively and normatively attractive: trying to break free from a self-sustaining territorial paradigm, Berman identifies entry-points for his community-based jurisdictional ideal in actual 'hybrid' (state/non-state) socio-legal practices (e.g., corporate self-regulation) on which future worlds could be built. ${ }^{58}$ Berman's theory may have been criticized as social rather than political, ${ }^{59}$ but he should surely be credited for highlighting the decreasing relevance of territory, and for foregrounding individuals' non-state community affiliations in the law of jurisdiction.

\subsubsection{Temporality}

Another jurisdictional alternative to address the current regulatory challenges is to move from the time-worn jurisdictional concepts of spatiality/territoriality and community, to temporality as a novel theoretical premise of jurisdiction. Mariana Valverde has usefully observed in this respect that ' $[\mathrm{t}]$ he machinery of jurisdiction is not tethered to or limited by spatial analysis', and that 'each mode of governance has one or more distinct temporalities'. ${ }^{60}$ She does not give clear suggestions as to how temporality could, in more practical terms, ground jurisdictional practices in the international field. ${ }^{61}$ Still, by highlighting the orientation of risk management strategies, notably in the environmental field, to future prevention, ${ }^{62}$ she gives at least an empirical indication.

It is known that in some functional domains of international law, the imperative to prevent future harm has informed temporal concepts such as intergenerational equity (pursuant to which resources should be responsibly managed now in the interest of future generations) ${ }^{63}$ or the precautionary principle (pursuant to which, even in the absence of a scientific consensus, regulatory action can be taken to avert dangers to health or the environment). ${ }^{64}$ 'Temporariness' has even been the theme of this Yearbook in 2014, with eleven contributions addressing various international law dimensions of the concept of time. ${ }^{65}$ None of these contributions addressed jurisdiction in particular. It is submitted here, however, that

\footnotetext{
${ }^{57}$ Berman 2005.

${ }^{58}$ See, at length, Berman 2012.

${ }^{59}$ E.g., Kaushal 2015, at 773.

${ }^{60}$ Valverde 2009, at 154 (emphasis added).

${ }^{61}$ In her Chronotopes monograph, she does apply temporality however to a number of municipal case studies, notably 'the honour of the Crown' in Canadian law (in respect of indigenous rights), feminism, and security. Valverde 2015, Chaps. 4-6.

${ }^{62}$ Valverde 2009, at 155.

${ }^{63}$ See, e.g., Brown Weiss 2007; Churchill and Freestone 1991.

${ }^{64}$ See, e.g., Cameron and Abouchar 1991; McIntyre and Mosedale 1997.

${ }^{65}$ Ambrus and Wessel 2015.
} 
temporality-based reasoning could play an innovative, although largely unexplored role in the law of jurisdiction.

For instance, the future risk of a global climate catastrophe could be invoked to buttress more expansive, non-territorial jurisdictional practices, where a state or regional organization such as the EU includes foreign operators and foreign emissions within its regulatory net, irrespective of territorial borders. Arguably, the currently suspended 'extraterritorial dimension' of the EU Aviation Directive, which required foreign airlines to surrender emissions allowances to the EU also in respect of mileage beyond the EU's borders, ${ }^{66}$ could be legitimated on the basis of a temporal version of jurisdiction-even if the CJEU famously justified the Directive's reach in territorial terms. ${ }^{67}$

Temporality is not only a useful analytical lens to jurisdictionally make sense of future risk but also of simultaneous occurrences, i.e., events occurring at the same time in different places. A classic spatial logic struggles to conceive of simultaneity in jurisdictional terms, as territoriality carries with it the assumption that an event takes place in one bounded space to the exclusion of other spaces. Admittedly, territorial jurisdiction could accommodate subsequent events in different places, notably via the continuous offense doctrine, by virtue of which multiple territorial sovereigns can exercise jurisdiction over an offence that has spatiotemporal continuity (e.g., conspiracy to commit fraud). ${ }^{68}$ However, territoriality cannot account for the same event arising simultaneously in different places. Technological changes have brought about just that: the advent of the Internet has allowed a multitude of geographically dispersed users to simultaneously experience the same activity, or

\footnotetext{
${ }^{66}$ The application of the EU's Aviation Directive was limited to emissions generated within EU airspace, see Regulation (EU) No 421/2014 of the European Parliament and of the Council amending Directive 03/87/EC establishing a scheme for greenhouse gas emission allowance trading within the Community, in view of the implementation by 2020 of an international agreement applying a single global market-based measure to international aviation emissions, [2014] OJ L 129/1.

${ }^{67}$ Air Transport Association of America and Others, para 125 ('In laying down a criterion for Directive 2008/101 to be applicable to operators of aircraft registered in a Member State or in a third State that is founded on the fact that those aircraft perform a flight which departs from or arrives at an aerodrome situated in the territory of one of the Member States, Directive 2008/101, inasmuch as it extends application of the scheme laid down by Directive 2003/87 to aviation, does not infringe the principle of territoriality or the sovereignty which the third States from or to which such flights are performed have over the airspace above their territory, since those aircraft are physically in the territory of one of the Member States of the European Union and are thus subject on that basis to the unlimited jurisdiction of the European Union') (emphasis added).

${ }^{68}$ Each state would have territorial jurisdiction as soon as a significant portion of the activities constituting that offence takes place on its territory. See Libman v The Queen, Supreme Court of Canada, Judgment, 2 SCR 178, 10 October 2015 (establishing jurisdiction over conspiracy to commit fraud arising out of the conduct of an individual's Toronto telephone sales solicitation room, from which sales personnel telephoned U.S. residents and attempted to induce them to buy shares in two Central American mining companies, with promotional material being mailed from Central America). For a US due process analysis of transnational conspiracy and territorial jurisdiction, see Althouse 1983.
} 
suffer harm arising from just one source. States may have used the cannon of territoriality to respond to online threats, but there is no denying that the instantaneous nature of the Internet is at loggerheads with a territorial logic. Conceiving of Internet offences in temporal terms surely does not solve the jurisdictional conundrum, but at least it draws attention to the obsolescence of territory, with its connotations of spatial exclusivity. It may allow us to reflect on the permissibility of 'extraterritorial' computer network searches by law-enforcement agencies, the rationale of which is to secure foreign evidence that with the click of a mouse, or even through automated processes may switch geographical location in a split second, without territorial sovereigns being even aware of the presence of the data on their territory. ${ }^{69}$ It may similarly invite us to ponder the legality of criminal warrants for the production of email account data stored by technology companies on a server located physically in a State's territory, bearing in mind that such data may just 'happen' to be located there, and may at will be geographically moved by the company or its automated processes. ${ }^{70}$

\subsubsection{Justice}

Finally, apart from community and temporality, justice, however construed, may also usefully inform alternative conceptions of jurisdiction which are not tethered to territoriality. Thus, Dorsett and McVeigh suggest an ethics-based 'jurisdiction of events that shapes the form of responsibility for freedom' ${ }^{71}$ This is a jurisdiction of conscience (of common humanity), the roots of which can be situated in Hannah Arendt's reflections on the Eichmann trial in Eichmann in Jerusalem. ${ }^{72}$ In this book, Arendt suggested jurisdiction as giving form to a new beginning in respect of genocide prosecutions. ${ }^{73}$

Truth be told, invoking Eichmann in Jerusalem as inaugurating a new conscience- or freedom-based form of jurisdiction replacing territoriality, may appear

\footnotetext{
${ }^{69}$ Wijziging van het Wetboek van Strafrecht en het Wetboek van Strafvordering in verband met de verbetering en versterking van de opsporing en vervolging van computercriminaliteit (computercriminaliteit III) (Proposal of Amendment of the Dutch Criminal Code and the Code of Criminal Procedure relating to the improvement and strengthening of the investigation and prosecution of cybercrime), https://www.eerstekamer.nl/9370000/1/j9vvhwtbnzpbzzc/vk0992hkwnxq/f=y.pdf, accessed 16 February 2016.

${ }^{70}$ In re Warrant to Search a Certain Email Account Controlled and Maintained by Microsoft Corporation (Microsoft Corporation v United States of America), United States District Court for the Southern District of New York (S.D.N.Y.), 15 F. Supp. 3d 466, 2014 (allowing such warrants), United States Court of Appeal for the Second Circuit, No. 14-2985, 14 July 2016 (disallowing them).

${ }^{71}$ Dorsett and McVeigh 2012, at 137.

${ }^{72}$ Arendt 1964.

${ }^{73}$ Note that Arendt also theorized 'new beginnings' in other settings, notably as regards constitutional institutions. See Palonen 2012.
} 
to be somewhat incongruous, as in respect of the atrocities of which Eichmann was accused, Arendt oddly suggested precisely territory as the appropriate principle of jurisdiction:

Israel could easily have claimed territorial jurisdiction if she had only explained that 'territory,' as the law understands it, is a political and a legal concept, and not merely a geographical term. It relates not so much, and not primarily, to a piece of land as to the space between individuals in a group whose members are bound to, and at the same time separated and protected from, each other by all kinds of relationships, based on a common language, religion, a common history, customs, and laws. ${ }^{74}$

Justifying Eichmann's trial on the basis of territorial jurisdiction, however, is farfetched in the absence of a territorial nexus, and also unnecessary. ${ }^{75}$ What Arendt really meant was basing jurisdiction on the injustice done to a community. ${ }^{76}$ In Eichmann in Jerusalem, this community was defined in a rather particularized manner as a community of Jews to which injustice was done, as she patently rejected universal jurisdiction on the legal ground that it was not incorporated in the Genocide Convention. ${ }^{77}$

However that may be, insofar as Arendt suggested that, in the Eichmann trial, justice had to be meted out and that jurisdictional principles should thus be oriented towards justice, her reflections on jurisdiction can be considered as signaling a new beginning indeed: one that is not necessarily based on territorial connections, nor even on personal links, but on the substantive wrongfulness of the act. Her stance ushered in a critical approach to the law of jurisdiction which is geared toward providing 'forms of jurisdiction adequate to the experience of those who engage with jurisdiction' and 'considering whether a jurisdiction was adequate to those who suffered the wrong of [an] event'. ${ }^{78}$ Obviously, a perception of injustice has already grounded instantiations of universal criminal jurisdiction over a number of crimes, but it could be used to underwrite more extensive corrective justice-based assertions of jurisdiction to remedy the undersupply of global public goods (e.g., environmental goods). ${ }^{79}$

\footnotetext{
${ }^{74}$ Arendt 1964, at 262-263.

${ }^{75}$ Luban 2011, at 633 .

${ }^{76}$ In this sense, Arendt's jurisdictional principle can be characterized as a hybrid of the passive personality and protective principle. See also ibid. ('What Arendt had in mind was a connection entirely unique to the Jews and the state of Israel ... The fanciful part is the claim that such jurisdiction is in any sense territorial').

77 Arendt 1964, at 262. The community takes on a universal form, however, in her correspondence with fellow philosopher Karl Jaspers in 1960, i.e., prior to Eichmann in Jerusalem. (Arendt to Jaspers, 23 December 1960: 'The only possibility seems to be to attach to the International Court at The Hague a criminal court for hostes generis humani that would be competent to try individuals regardless of nationality. As long as such a court does not exist, international law holds that any court in the world is competent - so why not Israel? Legally, Israel couldn't even claim it isn't competent.'), cited in Luban 2011, at 631-632; 1948 Convention on the Prevention and Punishment of the Crime of Genocide, 78 UNTS 277.

${ }^{78}$ Dorsett and McVeigh 2012, at 128

${ }^{79}$ Compare Krisch 2014.
} 
Recalling that visual attractiveness is what draws us to territoriality, it may be argued that justice-based, non-territorial jurisdiction can in fact measure up to territorial jurisdiction and has representational advantages that the other alternatives to territory may lack. True, justice-based jurisdiction cannot be visualized as a colored, bounded space on a cartographic map, but '[p]eople seeing injustice as governed by law, no matter where it is, will give meaning to universal jurisdiction $^{, 80}$ over atrocities. Pictures of injustice may galvanize public opinion support for universal jurisdiction. Moreover, the political imagery attendant to the actual exercise and visualization through the arrest of the presumed offender, as well as the screening of the trial may further harness the political power and authority of such jurisdiction. Accordingly, the concept of injustice could easily be paired with representational techniques that enhance its intuitive pull, thereby making it, at least in respect of a number of events, a palatable alternative to territory. Proponents of other 'extraterritorial' conceptions, such as community and temporality, would do well to explore more visual representations of their new jurisdictional beginnings with a view to becoming ingrained in the human psyche. ${ }^{81}$

\subsection{Reconceptualizing Territory}

Whatever the merits of the novel, non-territorial theoretical conceptualizations of jurisdiction set out in Sect. 3.4, there is no denying that they struggle to take root in actual legal praxis. This is largely because the territorial state, for better or worse, largely remains the sun around which the law's planets revolve. To be true, non-territorial transnational communities have, to a certain extent, developed their own regulatory capacities-witness transnational private regulation or the lex mercatoria $-{ }^{82}$ and thus seem to have carved out a jurisdictional space that enjoys autonomy vis-à-vis the state. In a sort of throwback to medieval times, members of such (functional) communities pledge allegiance to non-state, private governance systems, ${ }^{83}$ which sideline territoriality as a principle of jurisdictional order. ${ }^{84}$ Nonetheless, and this is an important point, such systems are usually embedded within the territorial state-based system, as states are the very creators of the systemic autonomy of non-state systems, through delegation, facilitation,

\footnotetext{
${ }^{80}$ Brigham 2009, at 401 (emphasis added).

${ }^{81}$ As neuroscientists have pointed out, human beings are visual beings indeed. Koch 2004, at 1107.

${ }^{82}$ Cafaggi et al. 2013; Berman and Kaufmann 1978.

${ }^{83}$ See more at length Callies and Zumbansen 2010.

${ }^{84}$ Backer 2012, at 122 (arguing that non-state actor governance, while having a limited scope, cross national boundaries, thus yielding the consequence that 'the old foundational notion of territoriality loses coherence as the marker par excellence of jurisdiction').
} 
orchestration, and management. ${ }^{85}$ A similar argument is made by Saskia Sassen in her acclaimed Territory, Authority, and Rights, where she argues that the novel spatio-temporal order results from new global assemblages being inserted in, or arising from the national/territorial. ${ }^{86}$ Reflecting on global financial markets, she observes that such markets make use of the capabilities entailed by territoriality. After all, such markets inhabit national territories, e.g., the City of London, ${ }^{87}$ while at the same time spanning them. This 'multi-sited territoriality' cannot be compared to the classic territoriality of the nation-state, but relies on state authority in the service of a global regime'. 88

Such an observation does not mean that territorial state regulation is necessarily being captured by private actors who simply use it as a device to further their own interests (although at times this may be part of the truth). ${ }^{89}$ The state may still have its own agency but may not just use its power to the benefit of a territorially delimited sphere. Rather, disposing of a monopoly on legal coercion and force, it remains a regulatory arbiter of political claims made by various actors and communities. Possibly, it cannot be otherwise, as plurality will almost inevitably lead to chaos in the absence of an overall normative-institutional framework that arbitrates between various conceptions of jurisdiction. In this sense, the time-honored territorial state, in spite of its defects and limitations, may remain the primary political community that 'pulls on other communities and repels other states', as a result of which jurisdiction is actually confluent (although not necessarily co-extensive) with the nation-state. ${ }^{90}$ Robert Jackson similarly believes that there is 'no realistic and practical alternative [to the state] even on the horizon'. ${ }^{91}$ But then again, the role of the state has changed. As Jens Bartelson reminds us in respect of sovereignty, while sovereignty is a fetish of political theory, it is mutable and 'no longer best understood as a constitutive attribute of states, but rather as something akin to a grant contingent upon its responsible exercise in accordance with the norms of the international community' ${ }^{92}$ Accordingly, to paraphrase Mark Twain, the reports of territory's death can be said to have been greatly exaggerated.

In the actual practice of state jurisdiction, there is no denying of this (re-)territorialization, understood not as the sort of bordered territoriality cum jurisdictional exclusivity of yesteryear, but as the redefinition of territory as a site for legal-political struggles which are informed by community, temporality, or justice-based arguments,

\footnotetext{
${ }^{85}$ Cf. ibid., at 98-100 (arguing that non-state actors cannot escape government, which keeps them like a dog on a leash, and thus that such actors operate in the shadow of hierarchy). See on state orchestration and facilitation of non-state regulation notably Abott and Snidal 2000.

${ }^{86}$ Sassen 2006, at 378 .

${ }^{87}$ Sassen 2006, at 386. See on global cities also Sassen's earlier work: Sassen 1991, 1994.

${ }^{88}$ Sassen 2006, at 418.

${ }^{89}$ Carpenter and Moss 2013.

${ }^{90}$ Kaushal 2015, at 774 .

${ }^{91}$ Jackson 2007, at 315.

${ }^{92}$ Bartelson 2014, at 69.
} 
and which are multi-scalar, i.e., not limiting themselves to the scale of the national, but extending to the regional and global. As Hannah Buxbaum has pointed out, 'activists, legislative reformers, and plaintiffs seeking recovery for harm suffered, are attempting to create a broader area of engagement for domestic courts through methods that rescale regulatory challenges'. ${ }^{93}$ Domestic courts, which are invariably imbricated with the territorial legal order of the state, then become arenas where global problems are fought over. ${ }^{94}$

At the same time, national or regional political authorities, unsatisfied with the slow pace of progress at the multilateral level, may take power in their own hands, ${ }^{95}$ and use territorial, border-based jurisdiction over foreign economic operators wishing to access a profitable territorial consumer or industrial market, with a view to pushing the international regulatory envelope. Recent EU measures of climate change unilateralism come to mind here, e.g., the aforementioned Aviation Directive, but also the recently adopted global emissions monitoring, reporting, and verification system imposed on foreign vessels docking in EU ports. ${ }^{96}$ Ideas floated for carbon-related border-adjustment taxes to mitigate climate change can be cited as well. ${ }^{97}$

The latter use of jurisdiction has attracted the attention of legal scholars recently, with Joanne Scott identifying it as a novel form of jurisdiction, named 'territorial extension'. ${ }^{98}$ This label of 'novel' may be exaggerated to the extent that the imposition, at the border, of national requirements on the bringing of goods or services within the territory goes to the heart of what jurisdiction in the modern era is all about: the regulation and limitation of movement, movement and mobility defining our modern condition. ${ }^{99}$ One of the characteristics of the new 'unilateral'

\footnotetext{
${ }^{93}$ Buxbaum 2004, at 173.

${ }^{94}$ Ibid., at 167: 'a global problem can be recast in local terms, in order to take advantage of local political or social resources. The concept of scale is therefore a useful analytical tool in examining how global economic misconduct is situated before the courts of one particular country.' Territorial courts are attractive as global dispute-resolution mechanisms especially when they are located in well-functioning states that have considerable regulatory and enforcement capacity, and are willing to construe their jurisdiction broadly. Such courts may exercise different forms of jurisdiction (territorial, personal, universal), but the important point is that they may offer an accessible, 'downscaled' forum where global legal-political struggles over jurisdiction can take place, in the absence of competent international courts.

${ }^{95}$ Cf. Hakimi 2014.

${ }^{96}$ Regulation (EU) 2015/757 of the European Parliament and of the Council of 29 April 2015 on the monitoring, reporting and verification of carbon dioxide emissions from maritime transport, and amending Directive 2009/16/EC [2015] OJ L 123/55.

${ }^{97}$ Kaufmann and Weber 2011.

${ }^{98}$ Scott 2014, at 90 (defining a measure as territorial extension where its 'application depends upon the existence of a relevant territorial connection, but where the relevant regulatory determination will be shaped as a matter of law, by conduct or circumstances abroad').

${ }^{99}$ As John Brigham observed: 'Jurisdiction regulates movement, where movement is the characteristic of modernity, first on foot, then by train, plane, and automobile over the countryside [...]. Jurisdiction is about stasis or at least limitations on movement. It is about the reach of law, and it suggests the more physical qualities of place that law defines.' Brigham 2009, at 382. In John
} 
territoriality is, however, that it does not only regulate movement (notably import of goods in the case) merely in the interest of the territorial state but also in the international interest, such as combating global climate change or furthering the fundamental rights of non-citizens. Territory accordingly becomes a managerial instrument $^{100}$ to reach for universal justice and protect global public goods. A global operator or a global problem's contact with a state's territory is seen to trigger the latter's territorial jurisdiction, but its effects are inevitably extraterritorial; they may affect foreign operators' global process and production methods, lead to modifications of foreign regulation (the term 'Brussels effect' is used to describe the impact of EU law on foreign regulation), ${ }^{101}$ and up the ante for better multilateral regulation. ${ }^{102}$ This process of redeploying territory is a fine example of a legal achievement resulting from using 'a social machinery geared to other ends'. ${ }^{103}$

\subsection{Acknowledging the Political Nature of the 'New Territoriality'}

The 'new territoriality', in particular the grafting of alternative jurisdictional concepts onto the time-honored territoriality principle, sketched in the previous sections, is not a stable category or process, because its nature and functioning is inherently political. This may not appear to be very different from any jurisdictional form. However, the political nature of the new territoriality is even more pronounced in that the blending of territory and 'its others' may yield a particularly undetermined and content-empty cocktail. It is then only through politicization that a concrete, although brittle shape can be given to these jurisdictional concepts. I understand politicization as the advancement of interest-based arguments by a

\footnotetext{
(Footnote 99 continued)

Locke's Second Treatise of Government (1689), we find one of the earliest modern expressions of this connection between movement and territorial jurisdiction: 'anyone who comes to enjoy [the] land-whether through inheritance, purchase, permission, or whatever-must take it with the condition it is already under, namely, submission to the government of the commonwealth under whose jurisdiction it falls'. Locke 2012, para 120.

${ }^{100}$ On the managerial approach to international law: Koskenniemi 2009, at 16-17 (characterizing 'managerialism' as a governance rationality which suggests that international problems should be resolved by developing increasingly complicated technical vocabularies for institutional policy-making).

${ }^{101}$ Bradford 2012; Kleizen 2015.

${ }^{102}$ E.g., the European Commission has 'stopped the clock' as regards the immediate application of the Aviation Directive to foreign operators in the order to give a multilateral emissions reduction solution within the International Civil Aviation Organization a chance. See European Commission (2012) Stopping the clock of ETS and aviation emissions following last week's International Civil Aviation Organisation (ICAO) Council, MEMO/12/854, 12 November 2012, http://europa.eu/ rapid/press-release_MEMO-12-854_en.htm, accessed 9 January 2017.

${ }^{103}$ Llewellyn 1930 , at 251.
} 
variety of societal actors (such as states, individuals, corporations, NGOs, international organizations) through given but open-ended jurisdictional categories. In both legal and political processes, these actors suggest rival jurisdictional interpretations in the hope of ultimately carrying the day by convincing their interlocutors, ${ }^{104}$ or relevant dispute-settlement mechanisms that are called upon to determine the law's jurisdictional reach. In this section I unpack and celebrate this 'politics of jurisdiction' that is central to the actual workings of the jurisdictional alternatives/new beginnings suggested above. In the next section, I apply these insights to the particular case of transnational human rights litigation, in which domestic courts arbitrate rival jurisdictional interpretations regarding the geographical reach of human rights protections.

The political character of the exercise of jurisdiction has lately gained the interest from legal theorists, who have so far largely shunned jurisdiction as an interesting field of research. Somehow, they may have relegated it to 'the technical' that is not amenable to theory formation. In part inspired by the anthropologist Annelise Riles's highlighting of the political character of even the seemingly most technical legal rules, ${ }^{105}$ theorists try to 'retrieve the space for the political in the study of jurisdiction'. ${ }^{106} \mathrm{~A}$ theorist would draw attention to the inaugural character of jurisdiction, jurisdiction being 'a means or instrument through which law asserts or withdraws its authority. ${ }^{107}$ Jurisdiction is, quite literally, the site of law speaking to itself, drawing attention to itself. ${ }^{108}$ For (substantive) law to apply, the regulator needs to have jurisdiction first. Accordingly, exploring jurisdiction more theoretically allows us to shed light on the moment just before law and governance comes into being. It allows us to draw the contours of the political community that sees itself as having jurisdiction over a particular space, event, group, etc., and being entitled to apply its particular laws. Sure enough, states and courts may apply seemingly technical rules of jurisdiction, as they are recognized in international law and laid down in domestic statutes. However, one should not overlook that these

\footnotetext{
${ }^{104}$ E.g., the Air Transport Association of America's direct challenge of the EU Aviation Directive before the Court of Justice of the EU (Air Transport Association of America and Others); foreign states' political protests against the reach of the Directive also after the CJEU's handed down its judgment (e.g., US European Emissions Trading Scheme Prohibition Act 2011 (HR 2494); Joint Declaration of the Moscow Meeting on the Inclusion of International Civil Aviation in the EU-ETS; China and India also condemned the action as not respecting the principle of common but differentiated responsibilities, this protest however appears to be informed by the desire to protect trade interests rather than by the opinion that the jurisdictional assertion violates international law, in particular the principle of non-intervention, see de Baere and Ryngaert 2013.

${ }^{105}$ Riles 2005.

${ }^{106}$ Kaushal 2015, at 760 .

${ }^{107}$ Ibid., at 779 .

${ }^{108}$ Brigham 2009, at 382.
} 
rules are in themselves political technology, and, moreover, that they cannot, as such, settle jurisdictional conflicts through straightforward categorization. ${ }^{109}$

As regards the character of jurisdictional rules as instantiations of political technology, it is recalled, as discussed above, that, in our Modern Age, political considerations, strengthened by the development of the science of cartography, have propelled territory to a dominant position in the law of jurisdiction, with some limited exceptions. Territoriality rose to power simply because it was deemed rational and strategically useful by political powers intent on entrenching and expanding their position of authority. It remains, though, that territorial jurisdiction is a historically contingent, socially constructed invention that is the result of unique historical circumstances in Western Europe. ${ }^{110}$ The organization of societal life could as well have been, and could become non-territorial. ${ }^{111}$ In Sect. 3.4, we have suggested a number of alternatives in this respect. However, even as territoriality has become the dominant mode of jurisdictional reasoning, or as territory has become the concept through which jurisdictional alternatives are filtered (cf. Sect. 3.5), politics does not recede. Territoriality suffers from, or more neutrally and accurately is characterized by its indeterminacy, just like other international law concepts. Koskenniemi famously explained in this respect that sovereignty, and with it the set of territorial rights and duties are not just something external to the law, which the law must recognize but cannot control (which he terms the 'pure fact view'), but also 'part of the law's substance, determined and constantly determinable within the legal system, just like any other norms' (which he terms the 'legal view'). ${ }^{112}$ This well-known indeterminacy critique reminds us, to paraphrase the Portuguese poet Fernando Pessoa, that '[territory] is what we make of it [...]. What we see is not what we see but what we are'. ${ }^{113}$ Thus, particular interpretations of territoriality, or extraterritoriality for that matter, are invoked by situated actors bent on furthering their own political, or other, interests, ${ }^{114}$ hoping to persuade

\footnotetext{
${ }^{109}$ Valverde 2008, at 14 (submitting that a 'merely technical analysis—such as those produced by appellate courts engaging in the work of allocating jurisdiction or policing its exercise-tends to reduce conflicts among competing powers/knowledges to a classificatory exercise of deciding what governing activity belongs in what drawer, a sorting process that obscures the incommensurabilities and the conflicts that see the under the surface in the most mundane of jurisdiction cases'). See also Liste 2014, at 14 (drawing attention to the 'perspective on the little litigation nothings that renders that hidden politics of space visible').

${ }^{110}$ See, inter alia, Ford 1999, at 929.

111 'Almost anything that is organized territorially could be organized in some other way.' Ford 2012, at 133; See also Berman 2005, at 1108 (arguing that nation-states with fixed territorial borders are not the only relevant jurisdictional entities).

${ }^{112}$ Koskenniemi 1990, at 14.

${ }^{113}$ Cf. Pessoa 2002: 'Life is what we make of it. Travel is the traveler. What we see isn't what we see but what we are'.

${ }^{114}$ Cf. Buxbaum 2009, at 635: “Territoriality” and "extraterritoriality" [...] are legal constructs. They are claims of authority, or of resistance to authority, that are made by particular actors with particular substantive interests to promote'.
} 
courts, other actors, or simply the invisible college of lawyers, of the superiority of their claim.

The inherent politicization of jurisdiction is not something to regret. Referring to politics in the context of the prima facie technical law of jurisdiction need not smack of bare-knuckle power politics in which authority is a function of money or brute force. Instead, it is simply an acknowledgement of the critical instability of the law of jurisdiction. Viewed in a positive light, politics in law allows for the (re-) constitution of the relevant political community, ${ }^{115}$ by creating an arena in which underlying normative conflicts come to the surface, and give rise to potential innovative solutions. ${ }^{116}$ This positive assessment of the role (to be) played by politics in international law, is by no means unique to the law of jurisdiction. Notably as regards international development, David Kennedy has suggested law as a 'terrain for the inquiry', a 'field of contestation', a complex of norms that renders more precise the political, distributional consequences of particular choices to be made. ${ }^{117}$ Partly drawing on Kennedy, Sundhya Pahuja has highlighted the political quality of international law, including its self-deconstructive character and its capacity for responsive change, which arguably makes law something more than just regulation, bare rules, and violence, a field that accommodates the possibility of difference. ${ }^{118}$ The open-ended, capacious character of international legal concepts may make them amenable to anti-hegemonic and subversive discourses, leading to a repositioning and redefinition of the original concept. However, there is no denying that a ruling rationality presented as universal and self-evident, but which is in fact driven by dominant political interests, may at times be difficult to overcome. ${ }^{119}$

In the law of jurisdiction, this ruling rationality is obviously state-based territoriality, but the capaciousness of jurisdiction may, as suggested above, allow for other expressions of political authority, e.g., based on transnational, global, or cosmopolitan ${ }^{120}$ conceptions of space, community, time, or justice. At the same

\footnotetext{
${ }^{115}$ Kaushal 2015, at 786 ('[J]urisdiction is not apolitical ... It is robustly implicated in politics and sovereignty, part of the original constitution of the polis as well as its ongoing reconstitution'). (emphasis in the original).

${ }^{116}$ Berman 2005, at 1126 (conceiving of jurisdiction as 'the locus for debates about the appropriate definition of community and the articulation of norms', constant search for balance).

${ }^{117}$ Kennedy 2003, at 20 and 26.

${ }^{118}$ Pahuja 2011, at 245-246 and 252.

${ }^{119}$ Ibid., at 250-251 (submitting that the "critical instability of international law creates the possibility for a level of resistance and redefinition within the bounds of an international legality but is repeatedly contained by a rationality that operates in terms of a claim for the universality of particular categories, terms, and ideas').

${ }^{120}$ Cosmopolitanism can either refer to a jurisdictional order based on transnational community affiliation (e.g., technology-based or commercial communities, diasporas), as advanced by Paul Schiff Berman (see Berman 2012), or to an order referring to a global community, in which actors strive for humanity's common good (justice).
} 
time, the capaciousness of territoriality itself, in its various dimensions (objective/subjective territoriality, quasi-territoriality, territorial extension, effects doctrine), may enable considerable political engagement. As highlighted above, territoriality may be explored to fulfill global objectives that are not spatially delimited. Moreover, in the globally interconnected world in which we live, events in one place may have 'butterfly' effects in far-flung places, ${ }^{121}$ thereby allowing multiple sovereigns to claim 'territorial' jurisdiction on the basis of minor connections, and often for political reasons (in the process, for that matter, diluting the ordering power of the principle of territoriality).

\subsection{Beholding Transnational Human Rights Claims: Donning Spatial and Non-Territorial Lenses}

In this last section, I move from the abstract to the concrete, and conduct a more grounded analysis of jurisdictional new beginnings, bearing in mind that normative arguments about jurisdiction need a specific empirical context lest they vanish into thin air. ${ }^{122}$ I have chosen to focus on transnational human rights litigation against corporations, ${ }^{123}$ as such litigation nicely teases out the political tug-of-war of the imbrications of alternative jurisdictional conceptions with the inherent territoriality of the domestic dispute-resolution forum offered. This focus also allows me to engage with some interesting interdisciplinary work recently published by Philip Liste regarding the case of Kiobel $v$ Royal Dutch Petroleum. ${ }^{124}$ In this-by now famous case, which many readers may already be familiar with-the US Supreme Court ruled that the US Alien Tort Statute (ATS) barred US federal courts from hearing foreign-to-foreign claims alleging corporate torts in violation of the law of nations, on the grounds that the ATS should be presumed not to apply extraterritorially. ${ }^{125}$ As a result, the Supreme Court refused to exercise jurisdiction over a

\footnotetext{
${ }^{121}$ The term 'butterfly effect' was coined by mathematician/meteorologist Lorenz to denote that small causes can have major (meteorological, e.g., hurricane) effects; see Lorenz 1963.

${ }^{122}$ Cf. Valverde 2009, at 146 ('Normative arguments about which scale is best make sense in concrete governance situations, in which one might indeed foresee the actual effects of choosing one scale over another, and thus make choices on the basis of concrete information. Without a specific, situated social/political issue whose practical implications can be examined, debates about scale can only be battles of abstractions').

${ }^{123}$ Transnational human rights litigation could be defined as litigation where victims and activists call on foreign courts to exercise their jurisdiction over violations committed overseas, sometimes by and against foreigners.

${ }^{124}$ Liste 2014, 2016.

${ }^{125}$ Kiobel v Royal Dutch Petroleum Co., Supreme Court of the United States, Opinion, 133 S.Ct. 1659, 17 April 2013 ('Kiobel'). The presumption against extraterritoriality is a long-standing canon of statutory construction in the United States. See for the seminal case: Equal Employment Opportunity Commission v Arabian American Oil Co. et al., Supreme Court of the United States, Opinion, 499 U.S. 244, 26 March 1991.
} 
claim brought by Nigerian citizens alleging that the oil corporation Royal Dutch Petroleum (Shell) had aided and abetted the government of Nigeria in committing violations of international law (in particular arbitrary arrest and detention, crimes against humanity, and torture or cruel, inhuman, and degrading treatment).

This final section does not purport to give a detailed overview of the role of territoriality in transnational human rights tort litigation. Such overviews, also from a comparative law perspective, have been offered elsewhere. ${ }^{126}$ Doctrinal analyses of Kiobel and the post-Kiobel era are also abundantly available in other publications. ${ }^{127}$ In this section, my only ambition is to engage at a theoretical level with the US Supreme Court's reasoning in Kiobel, and in particular to problematize territoriality, which was, via the presumption against extraterritoriality, so central to the solution of the dispute. I take Philip Liste's theoretical work on Kiobel as a foil to apply my own theoretical argument.

In his first publication on Kiobel, Liste highlights how the Supreme Court, relying on the presumption against extraterritoriality, naturalized territory, and obscured the political nature of social space - which may well have yielded alternative knowledge of spatial normativity, e.g., universal jurisdiction based on a transnational space. ${ }^{128}$ In his second publication, which consists mainly of an analysis of arguments centered on spatial normativity made in the various amicus curiae briefs in the Kiobel litigation, he demonstrates how various actors-states, multinational corporations, non-governmental organizations - conceive differently of the contours of territoriality and spatiality, depending on their social and political preferences. Most interestingly, he draws attention to how transnational corporations, somewhat counterintuitively perhaps, 'reproduce a highly territorialized knowledge of state jurisdiction', ${ }^{129}$ whereas (at least a number of) territorial states, including the forum state itself (the United States), make arguments that nuance territoriality, foreground the human rights interests of the aggrieved individual, and tentatively construct a global or transnational space ${ }^{130}$ Liste's analysis shows that a territorially delimited actor (the state) does not, as a matter of course, espouse a territory-based spatial discourse, and conversely, that a transnational actor (the corporation) does not per se develop transnational jurisdictional arguments.

As signaled above, states may well prove to be an enlightened trustee of mankind, willing to further the global public interest, and ready - within certain bounds obviously - to offer a territorial forum, or enact local legislation to address global problems. Private actors, for their part, may well turn to concepts almost belonging

\footnotetext{
${ }^{126}$ Enneking 2012.

${ }^{127}$ E.g., Alford 2014; Blaine 2014; Mora 2014.

${ }^{128}$ Liste 2014, at 17 and 19.

${ }^{129}$ Liste 2016, at 14-15 (citing the amicus briefs by Chevron et al., and BP America et al.) (emphasis added).

${ }^{130}$ Ibid., at 11-14, discussing the amicus briefs of the US, Germany, and Argentina. Note that The Netherlands and the United Kingdom, by contrast, formulate a more conservative territorial argument in their amicus brief, which is undeniably informed by their being the home countries of the defendant Royal Dutch Shell.
} 
to a bygone age, e.g., territorial exclusivity, that nevertheless remain part of the jurisdictional toolbox of states, thereby using, and in fact cherry-picking territorial state institutions that still command some authority, for their own private profit-making purposes. This recalls Sassen's observation that these territorial insertions - in the case the invocation of territorial sovereignty by a corporationare not constitutive of, or strengthen, state authority, unlike before, but rather articulate state authority in the service of a global, denationalized legal and political regime. $^{131}$

In Kiobel, the US Supreme Court ultimately experienced difficulties in conceiving of a global or transnational space, and could not escape from its self-imposed intellectual prison of territoriality. Despite the criticism that has been leveled at the 'conservative' Kiobel judgment, at a deeper conceptual level one should also concede, as indicated above, that imagining and representing the extraor non-territorial in spatial terms is hardly obvious given the enduring attractiveness of the territorial paradigm as world public order's cognitive script. Since 'space' is readily confused with physical 'place' and 'territory', proponents of 'global space' may perhaps expect too much from our human imagination. As suggested above, while I do think that it is not impossible to conceive of spatiality in non-territorial terms, possibly only a clear break with the existing geographic paradigm in imaging 'the global' can give rise to a veritable 'new jurisdictional beginning'. In this respect, I have suggested the alternative analytical lenses of justice, community, and temporality. I propose to don those lenses when having another look at Kiobel, and transnational human rights litigation against corporations more generally.

Donning the lens of justice in Kiobel, the US Supreme Court could have focused on the nature of the underlying violations alleged (Shell's alleged aiding and assisting the Nigerian government in committing acts of violence against local Ogoni people peacefully protesting against oil exploration projects). Put differently, it could have zeroed in on the Statute's jurisdiction ratione materiae rather than on its geographic reach, and could thus have established jurisdiction on the mere basis that gross injustice was alleged, possibly in combination with the conceptualization of space as 'global'. After all, going by its language, the ATS itself provides a cause of action for violations of the law of nations, ${ }^{132}$ which include gross human rights violations doing injustice to individuals. ${ }^{133}$

\footnotetext{
${ }^{131}$ Sassen 2006, at 418-420 (submitting that 'territorial insertions in a foreign country denationalize rather than produce an extension of national territorial authority' and describing 'partial and often highly specialized formations centered in particular utilities and purposes').

${ }^{132}$ Alien Tort Statute, 28 U.S.C. $\S 1350$ ('ATS') ('The district courts shall have original jurisdiction of any civil action by an alien for a tort only, committed in violation of the law of nations or a treaty of the United States').

${ }^{133}$ In Sosa v Alvarez-Machain, the Supreme Court found that the ATS did not create a cause of action, but instead merely 'furnish[ed] jurisdiction for a relatively modest set of actions alleging violations of the law of nations' (Sosa v Alvarez-Machain, Supreme Court of the United States, Opinion, 542 U.S. 692, 29 June 2004, at 720). Such actions must 'rest on a norm of international character accepted by the civilized world and defined with a specificity comparable to the features of the 18th-century paradigms we have recognized' (ibid., at 725) (emphasis added).
} 
In addition, donning the lens of community membership, one could argue that the Nigerian Ogoni people affected by Shell's oil exploration project formed part of the same community as Shell. It is recalled in this respect that the United Nations Global Compact coined the term sphere of influence 'to establish the scope of corporate responsibility for human rights issues based on the extent of a particular business' influence'. ${ }^{134}$ The idea is that a business can be considered to exercise influence over a variety of stakeholders, an influence that radiates beyond its premises and reaches not only its employees, but also suppliers, governments, and the wider community. While the UN Special Representative for Transnational Corporations and Human Rights has indicted the concept of sphere of influence as 'too broad and ambiguous a concept to define the scope of due diligence required to fulfil the [corporate] responsibility to respect', ${ }^{135}$ it remains a promising concept to delimit a relevant community for jurisdictional purposes. ${ }^{136}$ Accordingly, irrespective of the nature of the violation and irrespective of geographical location, the US Supreme Court in Kiobel could have decided to offer a jurisdictional forum to settle the dispute simply based on the joint community membership of plaintiff and defendant. ${ }^{137}$

An alternative outcome in transnational human rights cases of the sort of Kiobel could finally be ensured by donning the lens of temporality. More in particular, in such cases involving linked corporate actors and activities, the simultaneity iteration of the concept of temporality may allow for jurisdiction to be simultaneously established over a multitude of geographically dispersed actors who caused the same harm. This approach may yield jurisdiction over related claims brought against a variety of organizationally linked corporate wrongdoers. A temporal perspective may possibly not have changed the outcome in the Supreme Court case, as this case concerned just one actor-the Royal Dutch Shell parent corporation. However, it could have widened the number of defendants appearing in front of the Court. It is recalled in this respect that a lower court hearing the Kiobel case had refused to exercise personal jurisdiction over Shell's Nigerian subsidiary for lack of minimum contacts with the United States, as a result of which the case continued

\footnotetext{
${ }^{134}$ United Nations Office of the High Commissioner for Human Rights (2013) United Nations Global Compact, E-Learning, Module 2. http://human-rights-and-business-learning-tool. unglobalcompact.org/site/, accessed 17 February 2016.

${ }^{135}$ Ruggie J (2008) Clarifying the Concepts of 'Sphere of influence' and 'Complicity', Report of the Special Representative of the Secretary-General on the Issue of Human Rights and Transnational Corporations and other Business Enterprises, Eight Session of the Human Rights Council, UN Doc. A/HRC/8/16, 15 May 2008.

${ }^{136}$ The concept for that matter echoes the medieval concept of 'place', viewed as jurisdictional influence radiating outward from a geographic center (a town, a fortress) to outlying areas and their inhabitants (Branch 2013).

${ }^{137}$ This is provided that the US could establish personal jurisdiction over the defendant, on the basis of the latter's minimum contacts with the US.
} 
only against Shell's parent. ${ }^{138}$ Temporal sensitivity would instead have allowed the court to draw a link between the claims brought simultaneously against parent and subsidiary, in respect of the same harm, and exercise jurisdiction over the subsidiary, despite the latter not having minimum contacts with the US. ${ }^{139}$

An instructive precedent of purported temporal jurisdiction is offered by Dutch courts' jurisdictional rulings in Akpan $v$ Shell $(2013,2015)$, in a tort case related to Shell's oil operations in Nigeria (in the case concerning oil spills causing environmental damage). ${ }^{140}$ The main jurisdictional issue in Akpan v Shell was whether Shell's Nigerian subsidiary was amenable to suit in the Netherlands - apart from Shell itself, which was incorporated in the Netherlands and accordingly unambiguously subject to suit before Dutch courts under the domicile principle. ${ }^{141}$ Ordinary rules of jurisdiction did not provide for jurisdiction over alleged torts committed by foreign corporations against other foreigners on foreign soil, but regardless, Dutch courts ruled that the suits brought against the parent and subsidiary corporation were so much related that joint treatment-and thus extension of Dutch jurisdiction over the Nigerian subsidiary-was justified for reasons of procedural economy (efficiency). ${ }^{142}$ In so doing, the courts acknowledged that the complexity of international business transactions and corporate structures in a globalized world could be reduced by injecting simultaneity into the response offered by the law; where victims struggle to identify the responsible party among multiple potential defendants, it is advisable for courts to extend their jurisdiction to entertain claims against all defendants, including those of foreign origin, and thus to entertain the claims at the same time, in order to prevent inconsistent outcomes. ${ }^{143}$

A full acknowledgment of the drastic spatiotemporal changes in the global corporate value-chain could possibly have led to another jurisdictional outcome in

\footnotetext{
${ }^{138}$ Kiobel v Royal Dutch Petroleum Company, United States District Court for the Southern District of New York (S.D.N.Y.), No. 02 Civ. 7618 (KMW) (HBP), 2010 WL 2507025, 21 June 2010. Shell's parent corporation, however, operated an office in New York to manage its New York Stock Exchange listing. This was deemed sufficient to establish personal jurisdiction. The issue of personal jurisdiction was ultimately not before the US Supreme Court.

${ }^{139}$ Note also that the international law of responsibility has taken a particular interest in the responsibility consequences of multiple tortfeasors causing the same harm; notably the concept of 'shared responsibility'. See on this notion Nollkaemper and Jacobs 2012.

${ }^{140}$ See for the relevant jurisdictional judgments: Friday Alfred Akpan and Vereniging Milieudefensie v Royal Dutch Shell PLC and Shell Petroleum Development Company of Nigeria LTD, Hague District Court, ECLI:NL:RBDHA:2013:BY9854, 30 January 2013; and Hague Court of Appeal, ECLI:NL:GHDHA:2015:3587, 18 December 2015 ('Akpan v Shell').

${ }^{141}$ Articles 2(1) and 60(1) of Council Regulation (EC) No 44/2001 of 22 December 2000 on jurisdiction and the recognition and enforcement of judgments in civil and commercial matters, [2001] OJ L12/1.

${ }^{142}$ The courts applied Article 7 of the Dutch Code of Civil Procedure, which indeed provides for the joinder of cases in case of unity ('samenhang') of claims.

${ }^{143}$ This does not mean that territoriality disappears entirely. It only implies that one claim can piggyback on another claim over which uncontroversial jurisdiction can be exercised, such as on grounds of territoriality or domicile.
} 
Kiobel as well. In particular, it could have brought US courts to establish personal jurisdiction over Shell's Nigerian subsidiary alongside the Shell parent. True, in the Supreme Court, the case against the subsidiary would still have stranded on the ground of subject-matter jurisdiction under the ATS being absent. ${ }^{144}$ But then, when pondering the scope of ATS jurisdiction, the Court could have espoused an (admittedly unlikely) radical understanding of temporality with respect to the subject-matter jurisdiction it could exercise over both Shell and its Nigerian subsidiary, e.g., that the communication revolution had made corporate decision-making nearly instantaneous, thereby making a mockery of geography and territoriality. At any rate, in states that do not draw a precise distinction between personal and subject-matter jurisdiction - continental European states for instance - the form of temporality constituted by the connected claims doctrine may redefine and expand the exercise of jurisdiction over transnational torts.

This section has accordingly demonstrated that imagining jurisdiction using alternative conceptual lenses than the tired category of territory-global space, justice, community, temporality — may drastically change jurisdictional outcomes in transnational human rights litigation. Nevertheless, it bears emphasis that, however dramatic these re-conceptualizations of jurisdiction may appear, they do not necessarily do away with the state territory-based global order. Rather they invite us to imagine how new jurisdictional beginnings could be grafted onto the enduring institutions of the territorially bounded state, such as its domestic courts. They allow us to conceive of domestic institutions as fora for the resolution of global, rather than purely territorial, political and social conflicts.

\subsection{Concluding Observations}

International law's dominant positivist epistemology almost inevitably leads to 'territorial bias' on the part of its practitioners and scholars. This privileging of territory as the jurisdictional linchpin is indeed the logical outcome of a law-identification methodology that only takes seriously what states actually do and say. Territory being one of the basic features of statehood, ${ }^{145}$ it is not expected that states, in their legal practice and discourse, will abandon territory.

A critical scholar, however, denaturalizes the world-view and power relations that are reified by positivist, doctrinal scholarship. In particular, he critiques state

\footnotetext{
${ }^{144}$ The temporality lens donned here does not automatically make the claims actionable under the ATS, nor does it displace the presumption against extraterritoriality, as under US law, unlike under Dutch or European, courts should not only establish due process-based personal jurisdiction based on minimum links, but also subject-matter jurisdiction (does the claim fall within the substantive scope of the relevant statute?).

1451933 Montevideo Convention on Rights and Duties of States, 165 LNTS 19, Article 1.
} 
power-based scholarship. ${ }^{146}$ Historicizing territory is helpful in this respect, as it shows that 'territory' is a relatively recent 'invention' - the product of historically specific political, material, epistemic, and above all mapping practices - that points to the existence of a prior jurisdictional alternative: community. Drawing on inter alia Mariana Valverde's work, I have noted that critical analysis should go beyond the merely historical, however. This is why I have explored non-historical temporality $^{147}$ as well as ethics as resources allowing us to imagine forms of non- or extra-territorial jurisdiction that are based on time or justice, and not only on space.

Sure enough, such imagining may risk never leaving the ivory towers of academic philosophy. The task of the lawyer, however, is to inscribe bold governance ideas into the inevitable path dependency of our legal institutions, so that these ideas could inform actual decision-making. These institutions-e.g., the courtsremain largely territorial state-based, but they could repurpose themselves in the service of non-territorial jurisdictional aims, by inventively exploring the interstices of positive law. This 'new territoriality' holds promise for considerable political engagement through the law, as it enables non- or extra-territorial interests to take on a valid legal form. The example of transnational human rights litigation shows how such engagement can lead to legal outcomes that are quite surprising, but not necessarily less legitimate than those reached under the territorial paradigm.

\section{References}

Abass A (2014) International Law: Test, Cases, and Materials. Oxford University Press, Oxford Abbott KW, Snidal D (2000) Hard and Soft Law in International Governance. International Organization 54(3):421-456

Agnew J (1994) The Territorial Trap: the Geographical Assumptions of International Relations Theory. Review of International Political Economy 1(1):53-80

Akehurst M (1975) Jurisdiction in International Law. British Yearbook of International Law $46: 145-257$

Alford RP (2014) Human Rights After Kiobel: Choice of Law and the Rise of Transnational Tort Litigation. Emory Law Journal 63:1089-1161

Althouse A (1983) The Use of Conspiracy Theory to Establish in Personam Jurisdiction: A Due Process Analysis. Fordham Law Review 52:234-260

Ambrus M, Wessel RA (eds) (2015) Between Pragmatism and Predictability: Temporariness in International Law. Netherlands Yearbook of International Law 2014, vol 45. TMC Asser Press, The Hague

American Law Institute (1987) Restatement of the Law (Third): The Foreign Relations Law of the United States. American Law Institute Publishers, St Paul

Arendt H (1964) Eichmann in Jerusalem: A Report on the Banality of Evil. Penguin Books, London

\footnotetext{
${ }^{146}$ Valverde 2015, at 31 (defining critical theory as 'distancing oneself from that scholarship which is imbricated with state power').

${ }^{147}$ I am particularly indebted to Mariana Valverde in this respect, who in Chronotopes magisterially argued that time should not be reduced to history, and drew attention to the temporal dimension of 'human experience'. Valverde 2015, at 38.
} 
Backer LC (2012) Governance Without a Government: An Overview. In: Handl G, Zekoll J, Zumbansen P (eds) Beyond Territoriality: Transnational Legal Authority in an Age of Globalization. Martinus Nijhoff Publishers, Leiden, pp 87-126

Bartelson J (2014) Sovereignty as Symbolic Form. Routledge, London

Berman HJ, Kaufmann C (1978) Law of International Commercial Transactions (Lex Mercatoria). Harvard International Law Journal 19:221-277

Berman PS (2005) Conflict of Laws, Globalization, and Cosmopolitan Pluralism. Wayne Law Review 51:1105-1146

Berman PS (2012) Global Legal Pluralism: a Jurisprudence of Law Beyond Borders. Cambridge University Press, Cambridge

Bethlehem D (2014) The End of Geography: the Changing Nature of the International System and the Challenge to International Law. European Journal of International Law 25(1):9-24

Blaine JHL (2014) Sosa, Kiobel and Pirates Inc.: Defining the 'Modern' Parameters of the Archaic Alien Tort Statute. Hague Yearbook of International Law 26:116-140

Bradford A (2012) The Brussels Effect. Northwestern University Law Review 107:1-67

Branch J (2011) Mapping the Sovereign State: Technology, Authority, and Systemic Change. International Organization 65(1):1-36

Branch J (2013) The Cartographic State: Maps, Territory, and the Origins of Sovereignty. Cambridge University Press, Cambridge

Brigham J (2009) Seeing Jurisdiction: Some Jurisprudential Issues Arising from Law Being ‘... All Over'. Law \& Policy 31(4):381-404

Brilmayer L (1987) Jurisdictional Due Process and Political Theory. University of Florida Law Review 39:293-314

Brown Weiss E (2007) Climate Change, Intergenerational Equity, and International Law. Vermont Journal of Environmental Law 9:615-627

Buxbaum HL (2004) From Empire to Globalization....and Back? A Post-Colonial View of Transjudicialism. Indiana Journal of Global Legal Studies 11(1):183-189

Buxbaum HL (2009) Territory, Territoriality, and the Resolution of Jurisdictional Conflict. The American Journal of Comparative Law 57:631-675

Cafaggi F, Renda A, Schmidt R (2013) Transnational Private Regulation. In: OECD, International Regulatory Co-operation: Case Studies, vol 3. Transnational Private Regulation and Water Management. OECD Publishing, Paris, pp 9-58

Callies G, Zumbansen P (2010) Rough Consensus and Running Code: A Theory of Transnational Private Law. Bloomsbury Publishing, London

Cameron J, Abouchar J (1991) The Precautionary Principle: A Fundamental Principle of Law and Policy for the Protection of the Global Environment. Boston College International and Comparative Law Review 14(1):1-27

Carpenter D, Moss DA (2013) Preventing Regulatory Capture: Special Interest Influence and How to Limit It. Cambridge University Press, Cambridge

Churchill R, Freestone D (1991) International law and Global Climate Change. Graham \& Trotman, London

de Baere G, Ryngaert C (2013) The ECJ's Judgment in Air Transport Association of America and the International Legal Context of the EU's Climate Change Policy. European Foreign Affairs Review 18:389-409

de Vattel E (1834) The Law of Nations; or Principles of the Law of Nature Applied to the Conduct and Affairs of Nations and Sovereigns, Book II: Of a Nation Considered in Her Relation to Other States (edited by Chitty J). Cambridge University Press, New York

Dorsett S, McVeigh S (2012) Jurisdiction. Routledge, London

Douzinas C, Nead L (1999) Introduction. In: Douinas C, Nead L (eds) Law and the Image: The Authority of Art and the Aesthetics of Law. University of Chicago Press, Chicago, pp 1-15

Elden S (2013) The Birth of Territory. University of Chicago Press, Chicago

Enneking L (2012) Foreign Direct Liability and Beyond: Exploring the Role of Tort Law in Promoting International Corporate Social Responsibility and Accountability. Eleven International Publishing, The Hague 
Ford RT (1999) Law's Territory (A History of Jurisdiction). Michigan Law Review 97(4):843-930

Ford RT (2012) Law and Borders. Alabama Law Review 64:123

Greig JM (2002) The End of Geography? Globalization, Communications, and Culture in the International System. Journal of Conflict Resolution 46(2):225-243

Hakimi M (2014) Unfriendly Unilateralism. Harvard International Law Journal 55(1):105-150

Hirst M (2003) Jurisdiction and the Ambit of the Criminal Law. Oxford University Press, Oxford

Howse R, Regan D (2000) The Product/Process Distinction - An Illusory Basis for Disciplining 'Unilateralism' in Trade Policy. European Journal of International Law 11:249-289

International Bar Association (2009) Report of the Task Force on Extraterritorial Jurisdiction. International Bar Association, London

Jackson R (2007) Sovereignty and its Presuppositions: Before 9/11 and After. Political Studies 55 (2):297-317

Kassan S (1935) Extraterritorial Jurisdiction in the Ancient World. American Journal of International Law 29:237-247

Kaufmann C, Weber RH (2011) Carbon-Related Border Tax Adjustment: Mitigating Climate Change or Restricting International Trade? World Trade Review 10(4):497-525

Kaushal A (2015) The Politics of Jurisdiction. The Modern Law Review 78(5):759-792

Kennedy D (2003) Laws and Developments. In: Hatchard J, Perry-Kessaris A (eds) Law and Development: Facing Complexity in the 21st Century. Cavendish Publishing Limited, London/Portland, pp 17-26

Kleizen B (2015) Externalizing EU Law, Policy and Values: Europe's Global Identity, Mechanisms of Rule Transfer and Case Studies on Illegal Logging and Bosnia and Herzegovina. http://papers.ssrn.com/sol3/papers.cfm?abstract_id=2706564. Accessed 16 February 2016

Koch C (2004) Consciousness: Introduction. In: Gazzaniga MS (ed) The Cognitive Neurosciences III, 3rd edn. MIT Press, Cambridge/London, pp 1107-1110

Koskenniemi M (1990) The Politics of International Law. European Journal of International Law $1: 4-32$

Koskenniemi M (2009) The Politics of International Law - 20 Years Later. European Journal of International Law 20(1):7-19

Krisch N (2014) The Decay of Consent: International Law in an Age of Global Public Goods. American Journal of International Law 108(1):1-40

Landauer C (2014) The Ever-Ending Geography of International Law: The Changing Nature of the International System and the Challenge to International Law: A Reply to Daniel Bethlehem. European Journal of International Law 25(1):31-34

Langer M (2011) The Diplomacy of Universal Jurisdiction: The Political Branches and the Transnational Prosecution of International Crimes. American Journal of International Law 105:1-55

Lindahl H (2010) A-Legality: Postnationalism and the Question of Legal Boundaries. The Modern Law Review 73(1):30-56

Liste P (2014) Transnational Human Rights Litigation and Territorialised Knowledge: Kiobel and the 'Politics of Space'. Transnational Legal Theory 5(1):1-19

Liste P (2016) Geographical Knowledge at Work: Human Rights Litigation and Transnational Territoriality. European Journal of International Relations 22(1):217-239

Llewellyn KN (1930) Case Law. In: Seligman ERA, Johnson A (eds) Encyclopedia of the Social Sciences. MacMillan, New York

Locke J (2012) Second Treatise of Government: An Essay Concerning the True Original, Extent and End of Civil Government. John Wiley \& Sons, New Jersey

Lorenz EN (1963) Deterministic Nonperiodic Flow. Journal of the Atmospheric Sciences 20 (2):130-141

Lowe V, Staker C (2010) Jurisdiction. In: Evans MD (ed) International Law, 3rd edn. Oxford University Press, Oxford, pp 313-339

Luban D (2011) Hannah Arendt as a Theorist of International Criminal Law. International Criminal Law Review 11(3):621-641 
Maffesoli M (1995) The Time of the Tribes: The Decline of Individualism in Mass Society. Sage, London

Maier HG (1996) Jurisdictional Rules in Customary International Law. In: Meessen KM (ed) Extraterritorial Jurisdiction in Theory and Practice. Kluwer Law International, London, pp 64-102

Mann FA (1964) The Doctrine of Jurisdiction in International Law. Recueil des Cours 111:1-162

Mann FA (1984) The Doctrine of Jurisdiction Revisited after Twenty Years. Recueil des Cours 186:9-116

McIntyre, Mosedale T (1997) The Precautionary Principle as a Norm of Customary International Law. Journal of Environmental Law 9:221-242

Mora PD (2014) The Alien Tort Statute After 'Kiobel': The Possibility for Unlawful Assertions of Universal Civil Jurisdiction Still Remains. International \& Comparative Law Quarterly 63:699-719

Morgan LH (1877) Ancient society; Or, Researches in the Lines of Human Progress from Savagery, Through Barbarism to Civilization. Henry Holt and Company, New York

Nohria N (2012) What Business Schools Can Learn from the Medical Profession. Harvard Business Review 90(1-2):38-38

Nollkaemper PA, Jacobs D (2012) Shared Responsibility in International Law: A Conceptual Framework. Michigan Journal of International Law 34:359-438

Oxman BH (2007) Jurisdiction of States. Max Planck Encyclopedia of Public International Law. http://opil.ouplaw.com/view/10.1093/law:epil/9780199231690/law-9780199231690-e1436. Accessed 9 January 2017

Pahuja S (2011) Decolonising International Law: Development, Economic Growth and the Politics of Universality. Cambridge University Press, Cambridge

Palonen K (2012) The Search for a New Beginning: Hannah Arendt and Karl Jaspers as Critics of West German Parliamentarism. In: Goldoni M, McCorkindale C (eds) Hannah Arendt and the Law. Bloomsbury Publishing, London, pp 151-170

Pessoa F (2002) The Book of Disquiet. Penguin Books, London

Radon J (2004) Sovereignty: A Political Emotion, Not a Concept. Stanford Journal of International Law 40(2):195-209

Riles A (2005) A New Agenda for the Cultural Study of Law: Taking on the Technicalities. Buffalo Law Review 53:973-1033

Ruggie JG (1993) Territoriality and Beyond: Problematizing Modernity in International Relations. International Organization 47(1):139-174

Ryngaert C (2009) Territorial Jurisdiction Over Cross-Frontier Offences: Revisiting a Classic Problem of International Criminal Law. International Criminal Law Review 9:187-209

Ryngaert C (2015a) Jurisdiction in International Law, 2nd edn. Oxford University Press, Oxford

Ryngaert C (2015b) Whither Territoriality? The European Union's Use of Territoriality to Set Norms with Universal Effects. In: Ryngaert C, Molenaar EJ, Nouwen SMH (eds) What's Wrong with International Law? Liber Amicorum A.H.A Soons. Brill, The Hague, pp 434-448

Sack RD (1983) Human territoriality: A Theory. Annals of the Association of American Geographers 73(1):55-74

Sassen S (1991) The Global City. Princeton University Press, Princeton

Sassen S (1994) Cities in a World Economy. Pine Forge Press, Thousand Oaks

Sassen S (2006) Territory, Authority, Rights: From Medieval to Global Assemblages. Princeton University Press, Princeton

Schultz T (2008) Carving up the Internet: Jurisdiction, Legal Orders, and the Private/Public International Law Interface. European Journal of International Law 19(4):799-839

Scott J (2014) Extraterritoriality and Territorial Extension in EU law. American Journal of Comparative Law 62(1):87-125

Shah N (2012) The Territorial Trap of the Territorial Trap: Global Transformation and the Problem of the State's Two Territories. International Political Sociology 6(1):57-76

Shakespeare W (1623) Mr. William Shakespeares Comedies, Histories, \& Tragedies. Edward Blount and William and Isaac Jaggard, London 
Svantesson D (2015) A New Jurisprudential Framework for Jurisdiction: Beyond the Harvard Draft. American Journal of International Law Unbound 109:69-74

Treasure W (2011) Diagnosis and Risk Management in Primary Care: Words That Count, Numbers That Speak. Radcliffe Publishing, Oxford

Twain M (1907) Chapters from My Autobiography. The North American Review 185(618):465474

Vagias M (2014) The Territorial Jurisdiction of the International Criminal Court. Cambridge University Press, Cambridge

Valverde M (2008) Analyzing the Governance of Security: Jurisdiction and Scale. Behemoth A Journal on Civilisation 1(1):3-15

Valverde M (2009) Jurisdiction and Scale: 'Legal Technicalities' as Resources for Theory. Social \& Legal Studies 18(2):139-157

Valverde M (2015) Chronotopes of Law: Jurisdiction and Scale. Routledge, London

Wendt A (1999) Social Theory of International Politics. Cambridge University Press, Cambridge 